\title{
HUBUNGAN CAKUPAN IMUNISASI DASAR DAN ASI EKSKLUSIF DENGAN STATUS GIZI BALITA DI INDONESIA (ANALISIS DATA RISKESDAS 2018)
}

\author{
Ami Monika Sari *, Demsa Simbolon, Tetes Wahyu \\ Program Studi Diploma III, Jurusan Gizi Poltekkes Kemenkes Bengkulu \\ Jl. Indragiri Pd. Harapan No. 3 Padang Harapan, Kec. Gading Cempaka Kota Bengkulu, Bengkulu, 388225 \\ *Korespondensi : Email : amimonikasari@gmail.com
}

\begin{abstract}
Background: The direct causes of nutritional status problems are infectious diseases and inadequate intake. The prevalence of infectious diseases can be caused by children not getting complete basic immunization and not getting exclusive breastfeeding.

Objective: The study aims to determine the relationship between complete basic immunization and exclusive breastfeeding with the nutritional status of underfive children in Indonesia.

Methods: This study uses secondary data from Primary health research of Indonesia (Riskesdas 2018). It is an analytical study using a cross sectional study design. The sample in this study is toddlers spread across 34 provinces of Indonesia. The sampling technique in this study is the total population. The independent variables were complete basic immunization coverage and exclusive breastfeeding coverage. The dependent variable is the prevalence of nutritional status based on the index of Weight by age, body length according to age and body weight by length.

Results: The results of the analysis found that the complete basic immunization coverage for underfive children in Indonesia was 56.18\%, exclusive breastfeeding coverage was 39.59\%, and the prevalence of underweight and severely underweight children under five (WHZ) was 16.67\%, the prevalence of short and very short toddlers short (WHZ 29.68\% and the prevalence of malnutrition and very poor (HAZ) 12.44\%. using correlation test and linear regression with a significance degree of $p \leq 0.05$. Complete basic immunization coverage was associated with the prevalence of very underweight and underweight $(p=0.005)$, short and very short ( $p=0.043)$, very undernourished and undernourished $(p=0.000)$.

Conclusion: There is a significant relationship between complete basic immunization and the nutritional status of children under five in Indonesia. There is no significant relationship between exclusive breastfeeding and the nutritional status of children under five in Indonesia.
\end{abstract}

Key words: Complete basic Immunization; Exclusive breastfeeding; Nutritional status; Underfive years old

\begin{abstract}
ABSTRAK
Latar belakang : Penyebab langsung masalah gizi adalah penyakit infeksi dan ketidakcukupan asupan. Penyakit infeksi dapat disebabkan oleh imunisasi dasar yang tidak lengkap dan tidak mendapat ASI eksklusif.

Tujuan : Penelitian bertujuan untuk mengetahui hubungan imunisasi dasar lengkap dan ASI eksklusif dengan status gizi balita di Indonesia.

Metode : Penelitian menggunakan data sekunder hasil Riskesdas 2018. Mengambarkan tudi analitik dengan menggunakan desain studi cross sectional, Sampel pada penelitian ini adalah balita 34 provinsi yang ada di Indonesia. Teknik sampling dalam penelitian ini adalah total populasi. Variabel independen adalah cakupan imunisasi dasar lengkap dan cakupan ASI eksklusif. Variabel dependen adalah prevalensi status gizi berdasarkan indeks $\mathrm{BB} / \mathrm{U}, \mathrm{PB} / \mathrm{U}$ dan $\mathrm{BB} / \mathrm{TB}$

Hasil : Hasil analisis menemukan cakupan imunisasi dasar lengkap pada balita di Indonesia 56,18\%, cakupan ASI eksklusif 39,59\%, dan prevalensi balita berat badan kurang dan sangat kurang (BB/U) 16,67\%, prevalensi balita pendek dan sangat pendek (PB/U) 29,68\% dan prevalensi gizi kurang dan sangat kurang (BB/TB 12,44\%. menggunakan uji korelasi dan regresi linier dengan derajat kemaknaan $p \leq 0,05$. Cakupan imunisasi dasar lengkap berhubungan dengan prevalensi berat badan sangat kurang dan kurang $(\mathrm{p}=0,005)$, pendek dan sangat pendek $(\mathrm{p}=0,043)$, gizi sangat kurang dan gizi kurang $(\mathrm{p}=0,000)$. Prevalensi status gizi tidak berhubungan dengan cakupan ASI eksklusif.

Kesimpulan : Terdapat hubungan yang signifikan antara imunisasi dasar lengkap dengan status gizi balita di Indonesia. Tidak terdapat hubungan yang signifikan antara ASI eksklusif dengan status gizi balita di Indonesia. Kata kunci: ASI eksklusif; Balita; Imunisasi Dasar Lengkap; Status Gizi
\end{abstract}




\section{PENDAHULUAN}

Balita merupakan kelompok umur yang rentan dengan masalah kesehatan dan gizi. ${ }^{1}$ Status gizi balita dipengaruhi oleh berbagai faktor, diantaranya asupan gizi dan penyakit infeksi. Imunisasi berperan penting dalam pembentukan kekebalan tubuh balita, karena anak yang mendapatkan imunisasi lengkap jika daya imun kuat maka akan terhindar dari penyakit infeksi. Secara umum cakupan imunisasi lengkap di Indonesia pada anak umur 12-23 bulan sebanyak 57.9\% mendapatkan imunisasi lengkap, 32.9\% yang imunisasi tidak lengkap dan $9.2 \%$ yang tidak mendapatkan imunisasi berdasarkan data riset kesehatan dasar. Angka tersebut belum mencapai target renstra tahun 2019 yaitu sebesar $93 \% .^{2}$

Balita yang tidak mendapat ASI eksklusif memiliki dampak yang tidak baik untuk kesehatan salah satunya yaitu mengalami penyakit infeksi. Pemberian ASI kurang dari 6 bulan lebih berisiko dari pada balita yang diberikan asi 6 bulan infeksi dan kekurangan gizi, kehilangan mineral tubuh, serta penghambatan pertumbuhan yang mengakibatkan gizi buruk dan kejadian stunting pada anak. ${ }^{3}$ Di Indonesia hanya $52 \%$ anak berumur di bawah 6 bulan mendapat ASI eksklusif. ${ }^{4}$ Angka tersebut belum mencapai target nasional cakupan ASI eksklusif di Indonesia $80 \%$ dan tentunya sudah menjadi salah satu penyebab masalah gizi. ${ }^{5}$ Indonesia termasuk dalam 17 negara yang memiliki tiga masalah gizi pada anak balita yaitu tunting, wasting, dan kelebihan berat badan. ${ }^{6}$

Masalah stunting adalah salah satu masalah gizi yang banyak dialami oleh balita di dunia saat ini. ${ }^{7}$ Dari data World Health Organization (WHO) 2018 menunjukan pada tahun 2017 sebesar 22,2\% atau sekitar 150,8 juta balita di dunia mengalami stunting. Dari 83,6 juta balita stunting di Asia, proporsi terbanyak berasal dari Asia Selatan (58,7\%) dan proporsi paling sedikit di AsiaTengah $(0,9 \%)$. Indonesia juga termasuk negara ketiga dengan prevalensi tertinggi di regional Asia Tenggara Rata-rata prevalensi balita stunting di Indonesia tahun 2005-2017 adalah 36,4\%. ${ }^{2}$ Gizi kurang merupakan salah satu masalah gizi terbesar pada balita di Indonesia. Data Riskesdas (2018) prevalensi status gizi balita menurut indeks $\mathrm{BB} / \mathrm{U}, \mathrm{PB} / \mathrm{U}$ dan $\mathrm{BB} / \mathrm{PB}$, prevalensi gizi buruk 3,9\% dan 13,8 gizi kurang berdasarkan indeks BB/U. Prevalensi yang pendek berjumlah 19,3\% sangat pendek $11,5 \%$, menurut indeks $\mathrm{PB} / \mathrm{U}$, prevalensi sangat kurus berjumlah $3,5 \%$, kurus 6,7\% indeks BB/PB. Hasil Riskesdas 2018 menunjukan bahwa $30,8 \%$ balita Indonesia mengalami stunting dan sekitar $10,2 \%$ balita mengalami gizi kurang (wasting) ${ }^{8}$ Masalah gizi pada balita di Indonesia belum mencapai target rencana pembangunan jangka menengah nasional (RPJMN tahun 2020 yaitu $7 \%$ gizi buruk dan $19 \%$ stunting. ${ }^{9}$

Status gizi balita dapat berakibat fatal terhadap beberapa aspek. Gizi kurang pada balita akan berdampak tidak baik terhadap pertumbuhan badan maupun otak. ${ }^{9}$ Berdasarkan hasil penelitian Sowwam (2018) menunjukkan bahwa ada hubungan antara kelengkapan imunisasi dengan status gizi anak balita. ${ }^{11}$ Penelitian Jamil (2020) sejalan dengan penlitian Sowwam yang menunjukan bahwa ada hubungan antara kelengkapan imunisasi dengan status gizi anak balita. ${ }^{6}$ Namun berbeda dengan penelitian yang di lakukan oleh Hayyudini (2017) menunjukkan bahwa tidak ada hubungan yang signifikan antara status imunisasi dasar dengan status gizi anak. ${ }^{12}$

Pemerintah Indonesia merancang gerakan untuk pembangunan berwawasan kesehatan sebagai rencana pembangunan nasional untuk mewujudkan Indonesia sehat, dalam membangun masyarakat yang berwawasan sumber daya manusia (SDM) dimana strateginya meningkatkan status gizi masyarakat dan penanggulangan masalah gizi untuk menurunkan angka kematian bayi dan balita terus digerakan. Imunisasi merupakan program penting dalam rangka percepatan perbaikkan derajat kesehatan, karena Penyakit infeksi merupakan penyebab gizi buruk bahkan kematian anak. ${ }^{13}$ Belum tercapainya target cakupan imunisasi dasar lengkap dan cakupan ASI eksklusif, menyebabkan prevalensi masalah gizi balita di Indonesia masih tinggi, hasil penelitian masih kontroversi tentang hubungan imunisasi dan ASI ekkslusif dengan status gizi, Penelitian ini bertujuan untuk menjelaskan hubungan cakupan imunisasi dasar lengkap dan ASI eksklusif dengan status gizi balita di Indonesia agar dapat diketahui strategi yang lebih tepat dalam upaya menurunkan masalah gizi pada balita di Indonesia.

\section{METODE}

Penelitian menggunakan data Riskesdas 2018 dengan desain studi cross sectional. Populasi adalah seluruh balita yang tersebar di seluruh provinsi indonesia, Sampel pada 
penelitian ini adalah balita di 34 provinsi yang ada di Indonesia. Teknik sampling dalam penelitian ini adalah total populasi.Sumber data penelitian ini adalah data sekunder dari laporan Riset Kesehatan Dasar, Riskesdas 2018.

Instrumen penelitian mengikuti prosedur dari Riskesdas 2018 yaitu menggunakan kuesioner. Cara pengumpulan data yaitu dengan teknik wawancara dan pengukuran oleh tim penelitian Riskesdes. Dilakukan editing data untuk memastikan bahwa data yang diperoleh adalah data bersih yaitu data tersebut telah terisi semua, konsisten, relevan dan dapat dibaca dengan baik. Hal ini dilakukan dengan melakukan analisis atau pembersihan terhadap data yang hilang (missing data) sehingga tidak digunakan dalam analisis, tiap data dilakukan recoding untuk memudahkan keperluan analisa HASIL statistik dalam penelitian, Pembersihan data merupakan kegiatan pengecekan kembali data yang sudah dimasukkan (entry), apakah ada kesalahan atau tidak. Kesalahan tersebut mungkin terjadi pada saat kita entry data dicomputer, data tersebut yang sudah dimasukkan ke dalam komputer dan sudah diedit serta dicek kembali, dilakukan pengolahan data dengan menggunakan perangkat komputer yang menyediakan program untuk pengolahan/analisis data. Analisis data adalah proses penyederhanaan data ke dalam bentuk yang lebih mudah dibaca dan diinterpretasikan. Jenis analisis data yang digunakan dalam penelitian ini adalah analisis univariat yaitu ukuran tengah dan ukuran varian. Aalisis bivariat yaitu analisis dengan menggunakan statistika korelasi dan regresi linier sederhana.

Tabel 1. Gambaran Cakupan Imunisasi Dasar Lengkap dan ASI Eksklusif Balita di Indonesia

\begin{tabular}{lccccc}
\hline Variabel & $\mathrm{n}$ & $\begin{array}{c}\text { Minimum } \\
(\%)\end{array}$ & $\begin{array}{c}\text { Maximum } \\
(\%)\end{array}$ & Mean (\%) & SD \\
\hline Imunisasi dasar lengkap & 34 & 19,50 & 92,10 & 56,18 & 1,68 \\
ASI eksklusif & 34 & 20,30 & 56,70 & 39,59 & 9,18 \\
\hline
\end{tabular}

Berdasarkan Tabel 1 dapat dijelaskan bahwa cakupan imunisasi dasar lengkap di Indonesia $56,18 \%$ dengan rentang antara antara $19,50 \%$ sampai $92,1 \%$, dengan standar deviasi $1,68 \%$.
Cakupan ASI eksklusif di Indonesia antara $56,70 \%$ sampai dengan $20,30 \%$, dengan satandar deviasi $9,18 \%$.

Tabel 2. Gambaran Prevalensi Status Gizi Balita di Indonesia

\begin{tabular}{lccccc}
\hline Variabel & $\mathrm{n}$ & $\begin{array}{c}\text { Minimum } \\
(\%)\end{array}$ & $\begin{array}{c}\text { Maximum } \\
(\%)\end{array}$ & Mean (\%) & SD \\
\hline $\begin{array}{l}\text { berat badan sangat } \\
\text { kurang dan kurang }\end{array}$ & 34 & 24,50 & 10,60 & 16,67 & 3,80 \\
$\begin{array}{l}\text { sangat pendek dan } \\
\text { pendek }\end{array}$ & 34 & 38,80 & 16,20 & 29,68 & 4,93 \\
$\begin{array}{l}\text { gizi sangat kurang dan } \\
\text { gizi kurang }\end{array}$ & 34 & 17,40 & 4,80 & 12,44 & 2,91 \\
\hline
\end{tabular}

Berdasarkan Tabel 2 dapat di jelaskan bahwa prevalensi berat badan sangat kurang dan kurang berdasarkan indeks $\mathrm{BB} / \mathrm{U}$ di Indonesia antara $24,50 \%$, sampai dengan $10,60 \%$ dengan standar deviasi $3,80 \%$. Prevalensi sangat pendek dan pendek berdasarkan indeks $\mathrm{PB} / \mathrm{U}$ di
Indonesia antara 38,80\% sampai dengan 16,20\% dengan standar deviasi 4,93\%. Prevalensi gizi sangat kurang dan gizi kurang berdasarkan indeks BB/PB antara 17,40\% sampai dengan $4,80 \%$ dengan standar deviasi $2,91 \%$. 
Tabel 3 Hubungan Cakupan Imunisasi Dasar Lengkap dengan Status Gizi Balita di Indonesia

\begin{tabular}{lccccc}
\hline Status Gizi & Constan & $B$ & $r$ & $R^{2}$ & P value \\
\hline $\begin{array}{l}\text { BB/U berat badan Sangat } \\
\text { kurang + berat badan kurang }\end{array}$ & 22,61 & $-0,469$ & $-0,469$ & 0,220 & 0,005 \\
$\begin{array}{l}\text { PB/U Sangat pendek + pendek } \\
\text { BB/PB gizi sangat kurang + gizi }\end{array}$ & 19,04 & $-0,680$ & $-0,680$ & 0,462 & 0,000 \\
kurang & 35,41 & $-0,348$ & $-0,348$ & 0,121 & 0,0043 \\
\hline
\end{tabular}

Hasil pada Tabel 3 menunjukkan bahwa cakupan imunisasi dasar lengkap berhubungan dengan status gizi berdasarkan indeks $\mathrm{BB} / \mathrm{U}(\mathrm{p}=$ $0,005)$. Nilai koefisien korelasi $(r)=-0,469$ menunjukan kekuatan hubungan linier negatif sangat rendah, nilai kofisien determinasi $\left(\mathrm{R}^{2}=\right.$ 0,220 ) berarti imunisasi dasar lengkap dapat menjelaskan status gizi balita berdasarkan $\mathrm{BB} / \mathrm{U}$ sebesar $22,0 \%$. Hasil ini menunjukkan bahwa semakin rendah cakupan imunisasi dasar lengkap, maka semakin tinggi prevalensi balita berat badan sangat kurang dan kurang.

Hasil pada Tabel 3 menunjukan bahwa cakupan imunisasi dasar lengkap berhubungan dengan status gizi berdasarkan indeks $\mathrm{PB} / \mathrm{U}(\mathrm{p}=$ $0,000)$. Nilai koefisien korelasi $(r)=-0,680$ menunjukan kekuatan hubungan linier negatif sedang, nilai kofisien determinasi $\left(\mathrm{R}^{2}=0,462\right)$ berarti imunisasi dasar lengkap dapat menjelaskan status gizi balita berdasarkan $\mathrm{BB} / \mathrm{U}$ sebesar $46,2 \%$. Hasil ini menunjukkan bahwa semakin rendah cakupan imunisasi dasar lengkap, maka semakin tinggi prevalensi balita sangat pendek dan pendek.

Hasil pada Tabel 3 menunjukan bahwa cakupan imunisasi dasar lengkap berhubungan dengan status gizi berdasarkan indeks $\mathrm{PB} / \mathrm{U}(\mathrm{p}=$ $0,043)$. Nilai koefisien korelasi $(r)=-0,348$ menunjukan kekuatan hubungan linier negatif sedang, nilai kofisien determinasi $\left(\mathrm{R}^{2}=0,121\right)$ berarti imunisasi dasar lengkap dapat menjelaskan status gizi balita berdasarkan $\mathrm{BB} / \mathrm{U}$ sebesar $12,1 \%$. Hasil ini menunjukkan bahwa semakin rendah cakupan imunisasi dasar lengkap, maka semakin tinggi prevalensi balita gizi sangat kurang dan kurang.

Tabel 4. Hubungan cakupan ASI Eksklusif dengan Status Gizi Pada Balita di Indonesia

\begin{tabular}{lccccc}
\hline \multicolumn{1}{c}{ Status Gizi } & Constan & $B$ & $r$ & $R^{2}$ & $P$ value \\
\hline $\begin{array}{l}\text { BB/U berat badan sangat } \\
\text { kurang + berat badan } \\
\text { kurang }\end{array}$ & 13,86 & 0,172 & 0,172 & 0,029 & 0,332 \\
$\begin{array}{l}\text { PB/U sangat pendek + } \\
\text { pendek }\end{array}$ & 13,85 & $-0,113$ & $-0,113$ & 0,013 & 0,526 \\
$\begin{array}{l}\text { PB/BB gizi sangat kurang } \\
+ \text { gizi kurang }\end{array}$ & 31,54 & $-0,087$ & $-0,087$ & 0,008 & 0,624 \\
\hline
\end{tabular}

Hasil pada Tabel 4 menunjukan bahwa cakupan ASI eksklusif tidak berhubungan dengan status gizi berdasarkan indeks $\mathrm{BB} / \mathrm{U}(\mathrm{p}=$ 0,332) Nilai koefisien korelasi ( $\mathrm{r})=-0,172$ menunjukan kekuatan hubungan linier positif sangat rendah, nilai kofisien determinasi $\left(\mathrm{R}^{2}=\right.$ 0,029) berarti imunisasi dasar lengkap dapat menjelaskan status gizi balita berdasarkan $\mathrm{BB} / \mathrm{U}$ sebesar 0,29\%. Hasil ini menunjukkan bahwa semakin rendah cakupan ASI eksklusif, maka semakin rendah prevalensi balita berat badan sangat kurang dan berat badan kurang.

Hasil pada Tabel 4 menunjukan bahwa cakupan ASI eksklusif berhubungan dengan status gizi berdasarkan indeks $\mathrm{PB} / \mathrm{U}(\mathrm{p}=0,526)$. 
Nilai koefisien korelasi $(r)=-0,113$ menunjukan kekuatan hubungan linier negatif sangat rendah, nilai kofisien determinasi $\left(\mathrm{R}^{2}=0,013\right)$ berarti imunisasi dasar lengkap dapat menjelaskan status gizi balita berdasarkan $\mathrm{BB} / \mathrm{U}$ sebesar $0,13 \%$. Hasil ini menunjukkan bahwa semakin rendah cakupan ASI eksklusif, maka semakin tinggi prevalensi balita sangat pendek dan pendek.

Hasil pada Tabel 4 menunjukan bahwa cakupan ASI eksklusif berhubungan dengan status gizi berdasarkan indeks $\mathrm{BB} / \mathrm{PB}(\mathrm{p}=0,624)$. Nilai koefisien korelasi $(r)=-0,087$ menunjukan kekuatan hubungan linier negatif sangat rendah, nilai kofisien determinasi $\left(\mathrm{R}^{2}=0,008\right)$ berarti imunisasi dasar lengkap dapat menjelaskan status gizi balita berdasarkan $\mathrm{BB} / \mathrm{U}$ sebesar $00,8 \%$. Hasil ini menunjukkan bahwa semakin rendah cakupan ASI eksklusif, maka semakin tinggi prevalensi balita gizi sangat kurang dan kurang.

\section{PEMBAHASAN}

\section{Cakupan Imunisasi Dasar Lengkap}

Hasil penelitian menunjukan cakupan imunisasi dasar lengkap di Indonesia pada balita rata-rata $56,18 \%$ angka tersebut belum mencapai target RPJMN 2020 yaitu $80 \%{ }^{9}$. Apabila dibandingkan antara Provinsi tertinggi di Provinsi Bali 92,5\% hingga yang terendah di Provinsi Aceh 19,5\%.Cakupan imunisasi dasar lengkap di Indonesia bahkan lebih rendah jika di bandingkan di Kenya yaitu $76,6 \% .{ }^{14}$ Beberapa alasan ibu tidak membawa anaknya datang pada saat imunisasi yaitu karena tidak dapat izin dari suami, anak takut demam, anak sering sakit, tidak mengetahui tempat imunisasi, jauhnya tempat imunisasi dan ibu bekerja setiap hari. ${ }^{15}$ Rendahnya cakupan imunisasi dasar lengkap pada balita di Indonesia dikarenakan beberapa faktor, antara lain faktor pendukung yang terdiri dari karakteristik ibu seperti pekerjaan, pengetahuan ibu, sikap ibu, dan status ekonomi ${ }^{14}$

\section{Cakupan ASI eksklusif}

Pada penelitian ini menunjukan prevalensi cakupan ASI eksklusif di Indonesia rata-rata cakupan ASI eksklusif 39,59\% angka tersebut belum mencapai target nasional di Indonesia yaitu $80 \%$. Apabila dibandingkan antara Provinsi tertinggi di Provinsi Bangka Belitung 56,7\% hingga yang terendah di Provinsi Nusa Tengara Barat 20,3\%. Indonesia bahkan lebih rendah apabila dibandingkan dengan Negara-Negara
Eropa yaitu Kroasia 52,4\%, Georgia 54,8\%, Kirgistan $56,1 \% .{ }^{17}$ Beberapa faktor yang dapat mempengaruhi belum atau tidak tercapainya ASI eksklusif di Indonesia yaitu ASI tidak keluar, anak tidak bisa menyusu dikarnakan filek, ibu bekerja, rawat pisa, alasan medis, anak tidak tinggal dengan ibu nya, ibu meninggal, dan alasan lainnya. ${ }^{2}$ Keberhasilan ibu dalam pemberian ASI elsklusif dapat dipengaruhi oleh faktor internal dan eksterna, faktor internal yang mempengaruhi pemberian ASI eksklusif seperti pengetahuan yaitu informasi yang dapat dipahami seseorang ibu terhadap pentingnya memberikan ASI eksklusif, pendidikan yaitu diartikan sebagai suatu proses belajar mengajarkan kepada manusia untuk dapat berpikir, karena beberapa wanita yang bekerja biasanya takut dengan memberikan ASI secara eksklusif dapat merusak prospek peningkatan karier mereka adapun faktor eksternal yaitu promosi susu fermula bayi, Promosi tersebut dapat berasal dari iklan-iklan yang ada di tv. ${ }^{5}$

\section{Karakteristik Status Gizi}

Hasil penelitian menunjukkan prevalensi berat badan sangat kurang dan berat badan kurang di Indonesia rata-rata $16,67 \%$ angka tersebut menunjukkan belum mencapai target (RPJMN, 2020) yaitu 7\%.9 Apabila dibandingkan antara provinsi, tertinggi di provinsi Nusa Tengara Timur 24,5\% dan terendah yaitu di provinsi jawa barat 10,6\%. Indonesia menunjukkan lebih rendah jika dibandingkan Negara yang ada di Afrika yaitu Alergia 4,1\%, Angola 4,9\%, Benin 4,5\% dan Botswana 7,2\% ${ }^{18}$ Status gizi seorang anak dapat di pengaruhi oleh dua hal yaitu penyakit infeksi dan asupan makan yang kurang. ${ }^{13}$ Gizi buruk ialah masalah gizi yang dapat berakibat buruk pada kesehatan balita. Karena gizi buruk ini apabila tidak diatasi akan menyebabkan dampak yang buruk bagi balita. Gizi buruk dapat menimbulkan dampak pada penghambatan bagi pertumbuhan anak bahkan lebih serius seperti kematian. ${ }^{15}$

Hasil penelitian selanjutnya menunjukkan prevalensi status gizi sangat pendek dan pendek di Indonesia rata-rata $29,68 \%$ angka tersebut belum mencapa target (RPJMN, 2020) yaitu 19,\%. ${ }^{9}$ Jika di bandingkan antara provinsi yang tertinggi di Provinsi Kalimantan Utara 38,8\% hingga terenda di Provinsi DKI Jakarta 16,2\%. Indonesia bhakan lebih rendah jika di bandingkan Negara yang ada di Afrika yaitu Alergia $11,7 \%$, Burkina Faso 27,3\%, Congo 
$21,2 \%$, Gabon $17,5 \% .{ }^{18}$ Ada beberapa faktor yang dapat mempengaruhi kejadian stunting yaitu antara lain asupan ibu hamil, anemia ibu hamil,tinggi badan ibu, berat badan lahir, panjang badan lahir, pelayanan kesehatan (imunisasi), status ekonomi keluarga, jumlah orang di rumah, pengetahuan, kondisi kebersihan lingkungan dan air yang digunakan, pemberian ASI dan faktor infeksi, Panjang badan lahir merupakan salah satu faktor risiko stunting. ${ }^{3}$

Hasil penelitian menunjukkan prevalensi gizi sangat kurang dan gizi kurang di Indonesia rata-rata $12,44 \%$ angka tersebut belum mencapai target (RPJMN, 2020) yaitu 7\%.9 Jika di bandingkan atara provinsi tertinggi di Provinsi Nusa Tengara Barat dan Maluku 17,4\% hingga terendah Provinsi $\mathrm{K}$ alimantan Utara 4,8\%. Indonesia lebih rendah jika di bandingkan Negara yang ada di Afrika yaitu Zimbabwe $3,2 \%$, Zambia 6,3\%, Uganda 3,6\% dan Togo $6,7 \%$. ${ }^{18}$ Penyakit yang sering terjadi akibat masalah gizi antara lain diare, tuberkolusis, campak dan batuk, pola asuh orang tua juga berperan penting dalam pertumbuhan anak, orang tua harus memberikan perhatian yang lebih pada anak karena pola asuh merupakan interaksi antara anak dan orang tua selama mengadakan kegiatan pengasuhan karena mengasu adalah mendidik, mengurus makan, minum, pakaian dan kebersihan. ${ }^{16}$

\section{Cakupan Imunisasi Dasar Lengkap dengan Status Gizi}

Hasil penelitian ini menunjukan terdapat hubungan yang signifikan antara cakupan imunisasi dasar lengkap dengan status gizi berdasarkan indeks $(\mathrm{BB} / \mathrm{U})$ dengan nilai $\mathrm{p}=$ 0,005 . Status gizi berdasarkan indeks $(\mathrm{PB} / \mathrm{U})$ dengan nilai $p=0,043$. Status gizi berdasarkan indeks (BB/PB) dengan nilai $\mathrm{p}=0,000$. Berdasarkan hasil analisis korelasi dan regresi linier diperoleh ( $p$ value $<0.05$ ). berhubungan signifikan dengan prevalensi berat badan sangat kurang dan kurang, gizi sangat buruk dan gizi buruk dan stunting dengan korelasi berpola negatif, artinya semakin tinggi cakupan prsentase imunisasi dasar lengkap semakin rendah cakupan prevalensi berat badan sangat kurang dan kurang, gizi sangat buruk dan gizi buruk dan stunting. Hasil penelitian Wahyudi (2015) menjelaskan karena dengan sistem kekebalan dari imunisasi ini dapat membuat imunitas balita menjadi baik dan tidak mudah sakit apabila balita tidak melakukan imunisasi, maka kekebalan tubuh balita akan rentan terkena penyakit-penyakit menular, hal ini secara tidak langsung mempunyai dampak terhadap gizi buruk. ${ }^{19}$ Balita memiliki riwayat iminisasi dasar tidak lengkap mempunyai kemungkinan besar beresiko mengalami stunting 6 kali lebih besar dibanding dengan responden yang memiliki balita dengan riwayat imunisasi dasar lengkap. ${ }^{21}$ penelitian ini sejalan dengan penelitian yang dilakukan vindriana (2012) mengatakan ada hubungan yang bermakna antara kelengkapan imunisasi dengan status gizi. Imunisasi merupakan sesuatu yang sangat penting untuk meningkatkan status gizi yang baik. Imunisasi yang lengkap biasanya menghasilkan status gizi yang baik. Sebagai contoh adalah dengan imunisasi seorang anak tidak mudah terserang penyakit yang berbahaya,karena telah diberikan sistem kekebalan terhadap suatu penyakit sehingga anak lebih sehat, dengan tubuh/status sehat tentunya tidak mempengaruhi asupan makanan sehinga dapat masuk dengan baik, nutrisipun terserap dengan baik. Karena dengan nutrisi yang terserap oleh tubuh balita digunakan untuk pertumbuhannya, sehingga menghasilkan status gizi yang baik. ${ }^{22}$ penelitian ini juga sejalan dengan penelitian yang dilakukan Bhavsar (2013) mengatakan ada hubungan antara status imunisasi dan malnutrisi di Mumbai, ibu harus memahami dengan baik tentang kebutuhan gizi anak yang sedang tumbuh dan pentingnya imunisasi lengkap. Malnutrisi pada anak adalah penyumbang tunggal terbesar kematian balita karena kerentanan yang lebih besar terhadap infeksi dan pemulihan yang lambat dari penyakit. ${ }^{23}$ Akan tetapi penelitian ini tidak sejalan dengn penelitian yang dilakukan sumilat (2019) mengatakan status imunisasi dengan status gizi berdasarkan indeks $(\mathrm{BB} / \mathrm{U}, \mathrm{TB} / \mathrm{U}, \mathrm{BB} / \mathrm{TB})$ pada balita tidak ada hubungan, status gizi yaitu suatu keadaan tubuh dikarenakan mengkonsumsi makanan yang mengandung zat gizi. Status gizi menjadi penting karena merupakan salah satu faktor risiko yang mempengaruhi angka kesakitan dan kematian.Untuk itu, status imunisasi bukanlah faktor utama yang mempengaruhi status gizi tetapi ada hal lainnya yang mempengaruhi status gizi. ${ }^{12}$

\section{Cakupan ASI Esklusif dengan Status Gizi}

Dari hasil penelitian ini menunjukan bahwa tidak terdapat hubungan yang signifikan antara pemberian ASI eksklusif dengan status gizi berdasarkan indeks $(\mathrm{BB} / \mathrm{U})$ dengan nilai $(\mathrm{p}=$ $0,332)$. Status gizi berdasarkan indeks $(\mathrm{PB} / \mathrm{U})$ dengan nilai $(p=0,624)$. Status gizi berdasarkan indeks $(\mathrm{BB} / \mathrm{PB})$ dengan nilai $(\mathrm{p}=0,526)$. Berdasarkan hasil analisis korelasi dan regresi 
linier diperoleh ( $p$ value $>0.05$ ). ASI eksklusif 05 bulan pada Riskesdas 2018 merupakan komposit dari pertanyaan apakah bayi/anak masih disusui, selama 24 jam terakhir hanya diberi ASI saja, serta tidak diberi makanan/minuman lain .2

Penelitian Nugraheny and Alfiah (2015) menjelaskan bahwa yang di maksud ASI eksklusif yaitu pemberian ASI selama enam bulan tanpa pemberian makanan tambahan. Namun pengetahuan mengenai ASI eksklusif tersebut belum lakukan dengan penerapan pemberian ASI eksklusif. Hal ini sejalan dengan hasil penelitian yang dilakukan selvina (2015) mengatakan tidak ada hubungan yang signifikan antara ASI eksklusif dengan status gizi, karena status gizi tidak hanya di pengaruhi oleh ASI eksklusif saja juga dapat dipengaruhi oleh berbagai faktor, salah satunya yang dapat mempengaruhi pertumbuhan bayi adalah faktor nutrisinya. Makanan pendamping yang diberikan pada bayi usia 6-12 bulan merupakan salah satu faktor penting. Karena makanan tambahan dapat membantu memenuhi kebutuhan tubuh bayi untuk tumbuh kembang bayi yang tidak mendapatkan ASI Eksklusif. Memperkenalkan jenis makanan atau jenis makanan lokal merupakan faktor penting untuk memenuhi kebutuhan tubuh bayi. Hal tersebut dapat menjadi salah satu pilihan untuk mengurangi gizi kurang pada bayi. ${ }^{23}$ Namun berbeda dengan hasil penelitian yang dilakukan Sumilat (2019) mengatakan bahwa terdapat hubungan antara pemberian ASI eksklusif dengan status gizi pada balita status gizi yaitu suatu keadaan tubuh dikarenakan mengkonsumsi makanan yang mengandung zat gizi, pemberian ASI eksklusif suatu hal penting akan mempengaruhi status gizi karena ASI memiliki sumber zat gizi yang paling lengkap sesuai dengan umur anak yang harus diberikan kepada anak, agar pertumbuhan dan perkembangan (otak dan tubuh) baik. Status gizi menjadi penting karena merupakan salah satu hal yang berisiko memnyebabkan angka kesakitan dan kematian. ${ }^{12}$

\section{SIMPULAN}

Cakupan imunisasi dasar lengkap, ASI eksklusif dan status gizi balita di Indonesia belum mencapai target nasional. Cakupan imunisasi dasar lengkap 56,18\% dan cakupan ASI eksklusif $39,59 \%$. Balita Indonesia mengalami berbagai masalah gizi, $19,21 \%$ berdasarkan indeks BB/U, 30,26\% berdasarkan
$\mathrm{PB} / \mathrm{U}$ dan $10,87 \%$ berdasarkan BB/PB. Cakupan imunisasi dasar lengkap berhubungan linier negatif dengan prevalensi masalah gizi pada balita Indonesia. Semakin tinggi cakupan imunisasi dasar lengkap semakin rencah prevalensi masalah gizi. Cakupan ASI eksklusif tidak berhubungan dengan prevalensi masalah gizi balita di Indonesia.

\section{SARAN}

Berdasarkan hasil penelitian yang diperoleh dari data-data, pada dasarnya penelitian ini berjalan dengan baik. Namun bukan sesuatu kekeliruan apabila penelitian ingin mengemukakan beberapa saran yang mudamudahan bermanfaat, adapun saran yang peneliti ajukan sebagai berikut:

Membuat regulasi yang dapat mendukung petugas kesehatan masyarakat agar dapat meningkatkan cakupan imunisasi dasar lengkap dan ASI Eksklusif dan menurunkan status gizi buruk dan stunting, dan bagi tenaga non kesehatan perlu meningkatkan pengetahuan dan keterampilan dalam melaksanakan program ini, sehingga anak dapat tumbuh dan kembang dengan optimal sesuai umur anak untuk menciptakan generasi penerus yang cerdas pada masa yang akan datang.

\section{DAFTAR PUSTAKA}

1. Anggraeni R, Indrarti A. Klasifikasi Status Gizi Balita Berdasarkan Indeks Antropometri menggunakan Jaringan Saraf Tiruan. Snasti. 2010. P. 1-5.

2. Kemenkes. Hasil Utama Riset Kesehata Dasar (RISKESDAS). Book [Internet]. 2018;44(8):1-200.

3. Suharmanto. Hubungan pemberian asi eksklusif dengan status gizi balita relationship of exclusive breastfeeding with nutritional status of toddlers. Jk Unila. 2020;4:1-5.

4. BPS. Survey Demografi dan Kesehatan Indonesia. Survei Demogr dan Kesehat Indones. 2017;

5. Nugraheny E, Alfiah E. Faktor Penghambat dan penerapan ASI eksklusif. J Akbiduk. 2015;1-10.

6. Jamil SN, Subiyatin A. Hubungan riwayat imunisasi dengan status gizi balita. J Bidan Cerdas. 2020;2(3):1-7. 
7. Kemenkes RI. Buletin Jendela Data dan Informasi Kesehatan: Situasi Balita Pendek di Indonesia. Kementeri Kesehat RI. 2018;1-56.

8. Kemenkes. Rencana aksi kegiatan (RAK). Book. 2020;1-51.

9. Bappenas. Rencana pembangunan jangka menengah nasional 2020-2024. Jakarta; 2020. 1-319 p.

10. Rahim, k F. Faktor risiko underweight balita umur 7-59 bulan. J Kesehat Masy. 2014;9(2):1-7.

11. Sowwam, MW, Rejan B. Hubungan antara kelengkapan imunisasi dasar dengan status gizi pada anak usia 12-24 bulan di Desa Muhammad Sowwam. J Keperawatan CARE. 2018;8(1):1-9.

12. Hayyudini S, Yudhy. Hubungan karakteristik ibu, pola asuh dan pemberian imunisasi dasar terhadap status gizi anak usia 12-24 bulan (Studi Di Wilayah Kerja Puskesmas Kedungmundu Kota Semarang Tahun 2017). J Kesehat Masy. 2017;5(4):1-13.

13. Maina LC, Karanja S, Kombich J. Immunization coverage and its determinants among children aged 1223 months in a peri-urban area of Kenya. Pan Afr Med J. 2013;14:1-7.

14. Kemenkes RI. Riset Kesehatan Dasar. Jakarta: Kemenkes RI 2013.

15. Hafida W, Santi M, Shimarti RD. Faktor determinan status imunisasi dasar lengkap pada bayi di Puskesmas Konang dan Geger. BMJ. 2016;310(6984):1-8.

16. Bagci Bosi AT, Eriksen KG, Sobko T, Wijnhoven TMA, Breda J. Breastfeeding practices and policies in WHO European Region Member States. Public Health Nutr. 2016;19(4):1-12.

17. WHO. Atlas of African Health Statistics 2018. Geneva: WHO. 2018. 1-125 p.

18. Wahyudi, F, B. And Sriyono RI. Analisis faktor yang berkaitan dengan kasus gizi buruk pada balita. J Pediomaternal. 2015;3(1):1-9.

19. Windra Doni A, Yusefni E, Susanti D, Kartika Wulandari P. Hubungan panjang badan lahir dan riwayat imunisasi dasar dengan kejadian stunting balita. J Kesehat. 2020;13(2):1-14.
20. Vindriana V, Kadir A, Askar M. Hubungan kelengkapan imunisasi dengan status gizi pada balita usia 1-5 tahun di Kelurahan Watonea Wilayah Kerja Puskesmas Katobu Kabupaten Muna. Ejournal STIKES Nani Hasanuddin. 2012;1(2):1-8.

21. Bhavsar S, Mahajan H, Kulkarni R. Assessment of the nutritional status and immunization coverage of anganwadi children in Rafiq Nagar, Mumbai. Public Heal Res. 2013;2(6):1-7.

22. Sumilat MF, Malonda NSH, Hubungan antara status imunisasi dan pemberian asi eksklusif dengan status gizi balita usia 24-59 bulan Di Desa Tateli Tiga Kecamatan Mandolang Kabupaten Minahasa. J Kesmas. 2019;8(6):1-9.

23. Selvina S, Fadlyana E, Arisanti N. Hubungan pemberian ASI eksklusif dengan status gizi bayi umur 12 bulan. J Medis Althea. 2015;2(4):1-7. 